\title{
PReACHING AND THe Politics of Eschatological Memory
}

\author{
Ted A. Smith
}

\begin{abstract}
Now to the one who by the power at work within us is able to accomplish abundantly far more than all we can ask or imagine, to him be glory in the church and in Christ Jesus to all generations, forever and ever. Amen.
\end{abstract}

Ephesians 3:20-21 (NRSV)

A wise teacher of preaching once told me that a listener cannot really evaluate a sermon right after it has been preached. Because a sermon comes to life in the context of a shared and wider ministry, and because ministry bears fruit only over time, a sermon can be judged only by looking at the congregation after a decade of steady preaching, listening, and responding. Evaluating a sermon requires doing history.

But how much history would be enough? Why stop at ten years? Or twenty? Things could always change. Good fruit could be late in coming or soon to disappear. And unintended consequences, both good and bad, might not show themselves for generations. The problem of evaluation cannot be solved simply by extending the amount of time we wait. It requires instead a change in the register of time, and so a change in the quality of our waiting. The nature of preaching demands not just history, but eschatology.

Christians confess that the preaching of the Gospel begins and ends beyond our efforts. It begins before we speak. Faithful preaching is never a creation ex nihilo, but always a matter of engaging and handing on what we have received: the word of God already given in scripture, sacraments, and language itself. The word is from the beginning, prior in every sense to every sermon. It is the promise that makes preaching possible. Even so, the word is the longed-for destination of all our preaching, the fullness for which all creation yearns. Whatever truth our preaching has comes to life only as it is taken up into God's great work of reconciliation. And so it does not end in our speaking, or in our hearing, or even in our meditation and memory. It promises and hopes toward an end beyond its own history. In this it does not differ from, but only brings into sharper relief, the basic shape of all Christian practice.

How could one tell the story of such a practice? An authoritative account could only be told from the standpoint of the end of history, as in the genre that Hegel called "philosophical history."1 Hegel wrote his 
sweeping narratives of development, destruction, and fulfillment as if he stood very near to the end of time. If the end is not a place we can occupy, but only a gift we can receive, then a different genre will be required. It will be marked less by authority than by hope. It will involve stories told from a point the teller knows to be in anticipation of a greater end. While that great end does not provide the narrator's point of view, its presence still permeates the story. It is present in longing, in promise, and in expectation.

The story of Joseph and his brothers (Genesis 37-50), for instance, is told from a moment of reconciliation and salvation for the children of Israel-for the time being. At the end of the story, Joseph forgives his brothers for selling him into slavery and directs the resources of empire to sustain his family. "Even though you intended to do harm to me," Joseph says to his brothers, "God intended it for good, in order to preserve a numerous people, as he is doing today" (50:20, NRSV). Through and in spite of the brothers' sins, the covenant people will live on, and Jacob, the father of these rivalrous brothers, can die in peace. This is the end of Genesis, and its happy, ironic resolution might suggest that it is the end of the whole story. But as Genesis gives way to Exodus a new pharaoh arises, one who does not know Joseph. And now Joseph's careful plans, and even the gracious redemption of his brothers' treachery, become part of the story of Israel's enslavement. The end of Genesis, the end from which its stories are told, is not yet the great end for which the whole story hopes. While that great end does not come in the final chapters of the story, it is still present along the way. It appears, like the image of a photograph appears in its negative, in the conflicts between brothers. It flares up, briefly, in the hint of resolution that allows the story to continue. It is present, as a promise, in God's covenant with Abraham-the not-quiteforgotten backdrop against which the whole story unfolds (Genesis 12:1-3). That promise propels the story of Joseph and his brothers past its immediate ending to a higher hope: Israel will not only survive, but live to be a blessing to all the families of the earth. The ending of the story does not fulfill this higher hope, and the narrator who tells the story does not sit in the seat of this higher hope. The narrator rather stands before that seat, judged and redeemed with the story itself.

Like the narrator of the story of Joseph, we cannot occupy the place from which we could tell the full stories of sermons. For in speaking of sermons we remember a hope that outruns whatever narrative vantage point we have. We remember a promise that relativizes the time from which we tell the story, a hope that assures and warns us that we do not yet speak from the end. The full story of a sermon could only be told from a moment in which the promises latent in the sermon had been kept. The full story could only be read, as Theodor Adorno wrote, "by the light of redemption." ${ }^{2}$ Christians confess that redemption is both already accomplished in Jesus Christ and still to be hoped for. We proclaim that the reign of God is at hand and pray that it will come. Faithful stories of preaching will be marked by both the now and the not yet of redemption. They will not fuse but juxtapose empirical and theological modes of speaking. They will take the form not of philosophical histories, but of eschatological memories. 


\section{The Shape of Eschatological Memory}

Eschatological memories resist attempts to shape history into narratives of progress or decline. Narratives of progress and decline both rely on some fixed, final, morally charged endpoint that is continuous with all that has gone before. ${ }^{3}$ If the charge on the endpoint is positive, it flows from the end to make the whole story one of progress. And if it is negative, it makes the narrative into one of decline. But if sin and death never speak more than a penultimate word, then narratives of decline will be inadequate. They end too soon. And if the end of the story is not simply continuous with preceding events-if the fulfillment of the promise of history does not come as a result of history-then narratives of progress claim too much. What, for instance, is the narrative shape of the gospel of Mark? While the story drives to Jerusalem, the cross, and the glorious confusion of resurrection, it could not be called a story of progress. In the sense that the empty tomb is the fulfillment of every promise, the events of the story do not lead up to it. The cross creates a gulf, a gap, that no narrative can bridge. Gospel stories-and accounts of preaching should be included in this category-do not end in ways that can ground narratives of progress or decline. Because they end beyond themselves, they require a form that can hold hope and history together without erasing the difference between the two.

Recent histories of preaching in the United States have tended to take forms of progress or decline. Consider two different treatments of the "new measures," the practices for preaching associated with Charles Grandison Finney and other revival preachers of the 1820s through 1840s. Nancy A. Hardesty's Your Daughters Shall Prophesy celebrated the new measures as an important step in a progressive movement toward equal rights for women as preachers. Hardesty rightly named the new roles for women in speaking at revivals and in attending coeducational classes at Oberlin College, where Finney served as a professor and then as president. But Hardesty missed the many ways in which the moral authority of the new roles for women depended on the acceptance of a new set of constraints. Standing and binding came together. Nathan O. Hatch emphasized the binding effect of the measures in The Democratization of American Christianity, and so located them at the start of a narrative of decline. After the American Revolution, Hatch wrote, a band of innovators adapted elitist forms of Christianity to suit popular tastes-a process he called "democratization." The new measures codified those rowdy practices and made them respectable. With the move to respectability came a move away from popular tastes. The new measures, then, were a tipping point into a long slide away from a high-water mark of democratization. Hatch rightly saw the ways in which Finney offered respectability, but he missed the ways the new measures held desires for respectability together with commitments to equality. The two did not trade off strength in a zerosum game. They rose and thrived together as the new measures made the pursuit of a certain kind of equality into a badge of merchant-class respectability. Equality and respectability, like standing and binding, came together in a mutually reinforcing package. But if equality and a respectability that legitimated inequality increased together, the simple narrative form becomes 
problematic. A history of the new measures does not unroll easily toward some normatively charged end. The skeins of narrative tangle into knots. ${ }^{4}$

If the new measures are to be placed in relationship to some great end, some time of fulfillment, that end will not be a moment that is historically continuous with them. Their snarled stories do not run smoothly on, but tangle to a halt. If their stories are to be told with moral and theological significance, they will have to be told from the standpoint of an end they do not reach on their own, a perspective received now only in hope. For if they are to be redeemed, their redemption will come neither from a little more progress on the road they are already on, nor from a quick reversal to retrace their steps and then run in the other direction. It will come in death and resurrection, or not at all.

\section{On the Politics of Eschatological Memory}

As this example of appeals to equality suggests, eschatological memories reveal the migration of practices between religious and other spheres of society. Equality, for instance, is not just an abstract ideal, but a concrete bundle of practices that have moved freely between revival meetings, college classrooms, political rallies, and more. Practices of preaching have fit and helped form many core features of modern, democratic, consumer culture: not only the promise of equality, but also the dominance of instrumental reason, the desire for novelty, the demand for individual freedom, the transformation of sincerity into a cardinal virtue, and the creation of a sharp distinction between the material world and ultimate reality. Theological commentary on the practices of preaching, then, opens out into much wider social, cultural, and political commentary. Practical theology becomes political theology. ${ }^{5}$

Eschatological memories of sermons reveal connections and entanglements with the political sphere, but I also want to argue for a much more immediate sort of politics that grows out of eschatological memories: the politics necessary to sustain them. At first it might seem that an eschatological worldview dissolved the motives for any kind of political action. Why bother doing anything, with all these unintended consequences and ironic results? What is the point of working for equality if the very act of working for equality legitimates class difference? Why should a person seek to expand freedom if it will only tighten the straightjacket of being forced to choose? If purposeful activity itself has become over-conformed to a world of manic pseudoactivity, why try to do anything? These questions are only intensified if one understands the theology of eschatological memory as one in which God swoops in to redeem our sin-sick efforts and turn them into testimony, prayer, and discipleship. Why heal, if death will come and the body will be raised? Why preach, if the stones themselves will cry out? If our attempts to make history tie themselves in knots, and those knots bear witness in and in spite of themselves, why not give up on the project of ethics altogether? In fact, why not do evil, to tie the knots tighter, to maximize contradiction, that God might be all the more glorified?

What then are we to say? Should we continue in sin in order that grace may abound (Romans 6:1)? 
These are exactly the questions that Christian moral reasoning should generate. From Paul of Tarsus to Marguerite Porete to Martin Luther, the deepest attempts to grapple with the God made known in Jesus have drawn charges of antinomianism, libertinism, and moral nihilism. That so few works in the contemporary fields of Christian ethics and homiletics draw those charges should give us pause. It is as if Christian ethics and homiletics have become all exhortation and no exposition, a set of imperatives that have broken free from any declarations of Gospel to stand on their own. If my attempts at eschatological memories raise again the old questions, then it is their best work.

It is tempting to let the old questions hang unanswered, for answers threaten to restore the easy possibility of business as usual. But of course eschatological memories are part of business as usual, written this side of redemption. They pretend to nothing else. And so it is better to offer a few practical exhortations, especially if they appear as entirely unnecessary and perhaps even a threat to the larger project that I have been trying to sketch here.

A politics that can sustain the practices of eschatological memory revolves around confession, hope, and forbearance. Not just any sort of confession will do. Eschatological memory requires confession not only that we have failed to live up to our ideals, but that our ideals themselves-even the ideals of democracy, even the ideals of church-are mixed fields of wheat and tares, waiting for harvest. Eschatological memories flourish in social bodies that retain the capacity to confess when their best intentions produce perverse results. Such bodies must attend carefully to historical realities, not just their ideas about those realities, and not just the narratives in which those realities can be smoothly incorporated into a world that makes sense. Eschatological memories thrive among people who do not hide from confession under pleas of good intentions. These memories call out for people who can acknowledge their collaboration with the powers and principalities of this world, even those forms of collaboration that run deeper and wider than what we mean to do. Seeing that unnecessary but inevitable collaboration undercuts any attempt by a community of eschatological memory to understand itself as somehow outside of a fallen world. A politics that can bear eschatological memories refuses the temptation to understand itself as a Holy Oberlin, a Boomer commune, a gated community, or a church wholly other to the culture around it.

Eschatological memories require not only a particular sort of confession, but also a particular variety of hope. It is not the hope that we can achieve our country, let alone our church, let alone the reign of God, even with an invisible boost from supernatural helping hands. It is a hope that can bear the caesura between death and resurrection, the gap that waits for grace by the power of grace. It is a hope that can imagine God redeeming-if not necessarily causing or desiring-even the imperial wars of Cyrus, even the privileged resignation of Pilate, even the worship of pension funds and church property that holds more American Christians in eucharistic fellowship with their enemies than any exhortation ever could. Such hope is not the ability to look on the bright side, to see the silver lining to every cloud. Nor is it the willingness to call the rain cloud good, even as the flood waters wash away the farm. It is 
the refusal to imagine any corner of creation, any moment in time, as godforsaken. It is a confidence in a resourceful, improvising God who will not give up the pleasure of saying the last word. The hope of eschatological memory lives in but not as ideology. It tends to burrow deeply under attempts to light it up as a moving slogan or a powerful program. It risks coming closer to the surface of corny old saws: when the powers of this world offer lemons, God makes lemonade.

Because the hopes of eschatological memory extend even to enemies, a politics of eschatological memory will involve forbearance. Deep forbearance involves both more and less than giving another person the benefit of the doubt. It calls us to see friends and enemies alike in the hope that they are simul iustus et peccator, at once redeemed and sinful. It does not mean accepting anyone's beliefs and practices at face value, nor accepting the selfunderstanding of actors as normative. It involves a redeeming critique that reveals the ideological pretensions as mortified-but then refuses to ignore them as merely ideological. The forbearance of eschatological memory listens for the truths that the mortified remains of ideology tell, the hopes they have when delivered from their pretensions of fulfillment. It strains for ways to imagine even ideologies, even enemies, as caught up in redemption. ${ }^{6}$

The confession, hope, and forbearance of eschatological memory make possible a politics of piecemeal repair. If we will not bring in the Great Day, we can at least work to clean up the particular messes that we make, for the time being. As Walter Benjamin wrote, the concept of progress ceases to be critical when it is applied to the "historical process as a whole." can and must seek to make progress on more limited scales-especially by trying to redress the particular crimes that arise from and contradict our ideals. Most likely even our best attempts to repair the damage done by past wrongs will leave some wrong unrighted and do some new damage we cannot foresee. But piecemeal patching is possible, and we attempt it as a sign of our hope. That sign becomes all the more powerful as testimony when joined with a resignation to the fact that we will not accomplish our hope.

Such faithful persistence in ultimately useless activities enacts a critical witness in a society where usefulness threatens to usurp the whole concept of goodness. When human activity is taken to be the sum total of reality, useful activity assumes a supreme importance. To do nothing because we cannot do everything is still within the grip of this ideology. But to undertake practices knowing that they will accomplish eternal goods only in spite of us and believing that they are worth our lives begins to resist this ideology's moves to closure. It is to bear witness to another vision of reality. We do not persist in activities of hopeful inutility in order to bear witness (in order to be useful in another way). We simply do not stop tending sick lovers because we know they will not live forever, or working for campaign finance reform because even clean money will not bring real democracy, or preaching sermons like this one, because we know they fall short of the glory of God. A politics of eschatological memory proceeds in gratitude that redemption comes in, and in spite of, our best efforts. If we believed that, what reason would we have for ceasing to offer those best efforts to God?

A politics of eschatological memory therefore proceeds with a certain lightheartedness. Susan Sontag wrote that it is difficult for people with 
historical consciousness to take politics seriously. It is even more difficult for people who live by eschatological memories. But the leaven of lightheartedness can do wonders for both politics and preaching. A happy resignation to the fact that it is not all up to us can overflow in love for neighbor, praise of God, and work for peace that does not end in tyranny. It nurtures all those virtues that grow best just behind the back of the imperative to make the world a better place. Working for justice, forming friendships across lines of class and race, parenting, and singing praise to God only begin the list of practices best performed without gritted teeth. Of course these remarks can turn into one more set of imperatives: Be lighthearted! Have eschatological memories! And again I say, be lighthearted! Even the promise of hope slips into the imperative of an altar call. But the hope of eschatological memory lives within and without our hoping, just as it lives in and in spite of our preaching.

Ted A. Smith is Director of the Program in Theology and Practice and assistant professor of ethics and preaching at Vanderbilt University in Nashville, Tennessee.

\section{Notes}

1. See especially Georg W. F. Hegel, The Philosophy of History, trans. J. Sibree (New York: Prometheus Books, 1991).

2. Theodor W. Adorno, Minima Moralia: Reflections from a Damaged Life, trans. E. F. N. Jephcott (New York: Verso, 1978), 247.

3. As Benjamin wrote, "Overcoming the concept of 'progress' and the concept of 'the period of decline' are two sides of one and the same thing." Walter Benjamin, The Arcades Project, trans. Howard Eiland and Kevin McLaughlin (Cambridge, MA: Belknap Press of Harvard University Press, 1999), 460 (N 2, 5).

4. Nancy A. Hardesty, Your Daughters Shall Prophesy: Revivalism and Feminism in the Age of Finney (Brooklyn, NY: Carlson, 1991); Nathan O. Hatch, The Democratization of American Christianity (New Haven, CT: Yale University Press, 1989), esp. 196-200.

5. I consider each of these topics in Ted A. Smith, The New Measures: A Theological History of Democratic Practice (New York: Cambridge University Press, 2007).

6. I borrow the idea of redeeming critique (Rettendekritik) from Jürgen Habermas's exegesis of Walter Benjamin: Jürgen Habermas, “Walter Benjamin: Consciousness-Raising or Rescuing Critique," in On Walter Benjamin: Critical Essays and Reflections, ed. Gary Smith (Cambridge, MA: The MIT Press, 1988), 90-128. For a more complete discussion of my use of the term, see Ted A. Smith, "Redeeming Critique: Resignations to the Cultural Turn in Christian Theology and Ethics," Journal of the Society of Christian Ethics 24, no. 2 (Fall 2004), 89-113.

7. Benjamin, Arcades (N 13, 1). 